\title{
A Comparative Analysis between Latin American Magical Realism and Malaysian Realism: Intercultural Understanding through Literature
}

\author{
*Mireya Sosa Abella ${ }^{1}$ \\ Ricardo Mariano Reyes ${ }^{2}$ \\ University of Malaya
}

\section{Abstract}

"La luz es como el agua" (Light is like water), from the Colombian writer Gabriel Garcia Marquez, is part of a series of stories that belongs to what has been called Magical Realism in Latin American literature. On the other hand, Si Tanggang, from the Malaysian writer Abdul Samad Ahmad, has a stylistic approach which in literature has been called Realism. The analysis of the stories respond to the encounter and clash of two cultures from two literary tendencies called Magic Realism and Realism. "Light is like water" starts with realistic descriptions, but then adopts other narrative strategies in order to explain what goes beyond what is purely real. This is the moment when Realism becomes magical. Meanwhile, in the case of $\mathrm{Si}$ Tanggang, the narration has a more realistic approach. In the analysis of the two stories, two aspects will be considered. Firstly, the topics covered by the stories such as leaving one's place of origin and then returning to it, family values, and obedience towards parents. Secondly, the literary styles of these two tales, one belonging to Realism and the other one to Magical Realism.

Keywords: Magic Realism, Realism, Literature, Colombia, Malaysia. 


\section{Introduction}

\section{Outlines:}

Light is like water:

A family moves from the coastal Colombian city of Cartagena de Indias to the fifth floor of an apartment in Madrid, Spain. The two young boys, Toto and Joel, ask for a boat in return for their good grades. When their parents finally buy them the rowboat, they break the light bulbs in their home and the light comes flowing out like water. They use the light to navigate around their home every Wednesday while their parents are out at the cinema, and invite their friends to go sailing with them as well. The boys and their friends end up drowning in the light.

Si Tanggang:

${ }^{1}$ A son names Si Tanggang leaves his poor parents to make a fortune and promises to return for them. He rises up the ranks and even marries the daughter of his boss, but his promise is soon forgotten. When he accidently comes back to his homeland, he refuses to acknowledge them and his callous ways leads to tragedy.

An open the dialogue between East and West was proposed by Mohammed Khatami as it can be applied to distant cultures that, through mutual understanding, can reach an agreement of hope and coexistence (Dallmayr 2002). The present paper is an analysis of two short stories from societies that ignored this dialogue, and in doing so they got involved in processes of domination and disrespect. This brought tragedy as a consequence, which is exactly what Khatami wants to avoid through the use of real conversations among civilizations that would allow coexistence of mutual respect.

The analysis of the tales Light is like Water and Si Tanggang was initially intended to explain the characteristics 
of Realism and Magical Realism. In this paper, the analysis of the two stories will be done first individually and then comparatively. The analysis focuses on three issues: firstly, the return to the origins; secondly, an approach to some political processes carried out by nations before and after their independence; and finally, the meaning of tragedy. The similarities and differences between these two stories on the basis of these three issues are also studied here.

The story Light is like Water, extracted from the book titled Strange Pilgrims (1992) by García Márquez, and the story Si Tanggang Abdul Samad Ahmad, which was compiled in English by Badrie (2013) coincide on topics but with differences in the treatment of characters, space and time. The first tale makes part of what is known as Magical Realism in Latin American literature while the second tale makes part of the compiled Malaysian oral folktales that have undergone some transformations and modifications from generation to generation, and belongs to what is known as Realism in literature.

The analysis of the two stories responds to the points of encounter and divergence between two cultures on the basis of two literary movements known as Magical Realism and Realism. Both stories stray away from precise descriptions and become aesthetic creations when reflecting upon the world. Light is like Water contains realistic descriptions, however, it has to make use of other narrative strategies in order to emphasize on a reality which is full of events within natural and geographical settings that exceed the mere reality. This is the moment when Realism becomes magic (Uslar, 1986).

Although Si Tanggang deviates from very concrete events and descriptions to explain reality, which responds to a realistic narrative with a well-defined socioeconomic context, it is surprising that at the end of the story, there is an approach to the element of magic. Although it is not proper magic, it is noticeable that the story moves away from the narrative dynamics in which the story is conceived. The last part of the 
narration is more fantastic as it happens suddenly, while in Magical Realism, the magic component is present throughout the narration. Therefore, it is not a process, but a supernatural nuance: the power of the mother's words let God punish human behavior with his grandeur, since cruelty cannot be sentenced and punished in a different, perhaps more justified manner (Badrie, 2013).

\section{Methodology}

These two stories will be analyzed by comparing the topics covered in them as well as the styles of narration. The topics that will be analyzed are the cultural changes that the characters go through due to the socioeconomic factors which involve the physical transfer into unknown territories and the family values of the characters. As far as the styles of narration, these stories have opposite styles -one being Realism and the other Magical Realism- however they share certain style features.

Two stories were chosen: Light is like Water by the Colombian writer Gabriel García Máquez and Si Tanggang by the Malaysian writer Abdul Samad Ahmad, who compiled this story and others as a collection of folktales. These stories were chosen because the subject matter and style have some aspects in common; for instance, realism, identity, tragedy and nostalgia. There are differences in other aspects such as the use of magic elements, the precise identification of geographical places by Márquez, and the socio-economic difference of the characters in the two narrations due to the cultural background of each setting. The literary style of the first (i.e. Magical Realism) serves to contrast with that of the second author who belongs to what is known as Realism.

\section{Magical Realism}

Magical realism was not born in literature; it was mentioned for the first time by the German critic Franz Roh in 
1925 (Roh, 1927). He used the term to make reference to a group of post-expressionists ${ }^{3}$. Then, the term was used to define a certain style of Latin-American Literature from the 1940 's to the 1970's.

In literature, Magical Realism depicts the reality altered by actions and behaviors that are not possible to be explained from a rational perspective. However, from the literary point of view, these events are manifested as normal. The magic is not seen as something strange that amazes characters and readers. Instead, the magic becomes part of reality in the context of a novel or a tale (Pérez, 2002). Magical Realism is the way of showing Latin-American occurrences: history, nature, music and geography as well as the construction of nations after colonization. All in all, Latin America has gone through cultural and political processes that make it a unique, amazing and magical place. Magical Realism captures the essence of a continent that has gone through more than four centuries of colonization, in which Amerindian, African and European cultures converged in order to create a cultural syncretism rather than a dissociation (Neo, 2006). This diversity, as part of a whole, has created complex cultural processes and has become the essence of what we know today as Magical Realism (Uslar, 1984).

The exuberance of the American world had connections with the Asian world. According to Oscar Pujol, since Greek times, there were three images of India: "exoticism, richness and spirituality" (2008 in Gómez, 2011, p. 45). The first and second images are particularly found in the West Indies Baltazar Dorantes de Carranza, another chronicler, who wanted to prove the relation between the new world and a big and prestigious India. Baltazar Dorantes de Carranza (1987) and Columbus (1992) talk about the happiness and fertility of the new world, but Dorantes de Carranza considers such attributes to be part of the Far India. He also admires the natural, linguistic and racial diversity of the new continent (Gómez, 2011). 
The concept of time in Magical Realism is not linear; some of the events participate in the dynamics of dreams in which situations, characters and times are intertwined. Magical Realism takes up elements from surrealism and psychoanalysis present in Europe at the time when Magical Realism was the way to depict Latin America (Pérez, 2002). In Magical Realism, there are fantastic elements that become exaggerated as the narration goes by although it always starts from reality. These fantastic elements are events that cannot be explained with logical reasoning. Additionally, reality suffers a transformation by the world of dreams. Sometimes, the content of a dream is appended to the reality that is mentioned in the text. Nature has a relevant role; the tropic is often referred to due to its warm and natural complexity. Reality itself is permeated by magic, as magic is permeated by reality itself (Neo, 2006). Tales and novels are generally based on the Latin American society; the historic events are particular situations which acquire a special meaning because although they start with real historical events, they acquire surreal elements. The author would normally project his/her points of view, ideologies and political convictions (Carpentier, 2004).

\section{Realism}

Realism began in Europe in the middle of the nineteenth century (Barros, Gonzalez and Freire, 2006). Realism depicts customs and dialects from specific regions and shows the urban development to the detriment of the country. Cities become an apparent hope for those who migrate there, who are amazed by the progress and the perspectives offered by the socio-economic changes. The narrations also have not failed to highlight the new emerging social classes. Furthermore, there is a set of situations that depict a society that is putting aside the traditional values in order to assume new ones in accordance with the time they are going through. 
The socio-economic changes take place with a new philosophical school called Positivism, which studies reality as it is presented; that is, parting from exact observations and measurements. This is depicted by the literary narratives through very precise descriptions of places and human behaviors within a linear story line (Fernández, 2008). Although Si Tanggang was put in writing in 1955, it does contain some features which are indicative of this literary element.

Realism writers use everyday life in their works, which are seen from an aesthetic perspective, as manifested in $\mathrm{Si}$ Tanggang. In this sense, reality becomes a degrading phenomenon that needs to be changed, despite the fact that in the case of Si Tanggang, it is intended to give a moral lesson. According to Mohd Taib Osman (1989) and Muhammad Haji Salleh (2008), Malay literature has been preceded by oral tradition, which has a variety of forms and genres (Wan, 2013). Si Tanggang is located within this diversity of Malay folklore. It is in the nineteenth century when these tales began to be part of written texts due of the adoption of the Jawi script (Omics International, n.d). Nevertheless, it is after 1957 when the printed version increased, however great amount of this patrimony was lost when the people who narrated it vanished, especially during the war periods, such as the Japanese occupation.

\section{Literature Review}

Regarding "Light is like Water", Canfield maintains that the tale is a metaphorical dream that is materialized (Canfield, 1996). This critic considers this narration as part of the dreams of the author, as well as his poetic experience. Air and light are navigable just like water. Such equivalence, in her opinion, is presented by the paradoxical resource of the author (Canfield, 1996). Paradox is precisely what differs from common sense; that is, there are memories the author describes, which were imposed on a reality that he needed to 
prove twenty years later, when he returns to Europe and he discovers that everything has changed.

Water, the elevation of the terrain and the distance from the sea in which the children are forced to live in are another *important contrast.to where they come from. Madrid, their current place of residence, is opposed to Cartagena, their place of family provenance. The author has an aversion to high and cold lands. The children find a form of escapism by inventing a sea, but this experience logically ends up in tragedy. Canfield observes that for Bachelard (1991), the mysterious boats are part of the boats of the dead, and in the myths, death is seen as a journey through water. All of those who sail the boats remember Caronte, a mythological character who led the dead from one side of the Arqueonte River to the other. In this story, the children and their mates become Carontes (Canfield, 1996).

\section{Socio-Cultural Analysis}

\section{Light Is Like Water: A Manifestation of Magical Realism}

In the prologue to his work, García Márquez explains how these stories came about (García, 1992). The main interest of this collection of stories is the need to write about strange things happening to Latin Americans in Europe. The story takes place in Madrid. In addition, the subject matter of the twelve stories, including Light is like water, is related to the author's staying in Europe twenty years before the stories were written. Twenty years later, the author tries to compare the images he had kept in his mind and captures them in these twelve stories. However, those initial images prevailed over truth: the real memories were like ghosts, whereas the false memories were more convenient for his writings (Garcia, 1992).

Once García Márquez proved that his earlier experiences had changed, he decided to rewrite the stories. Thus, in his new version there was no distinction between reality and imagination. He believed his experience in Europe 
twenty years earlier to be false and then these stories appeared. Nevertheless, imagination took priority over the reality experienced by him.

Strange Pilgrims is part of Magical Realism, a literary style that belongs to the "Latin American Boom"; a literary phenomenon that lasted approximately from 1960 to 1970. It puts together some Latin American writers, who with their style and topics assert the Latin American culture. These writers transcend the borders of Latin America and are made known all over the world. The analysis scope of the short story Light is like water is part of this literary phenomenon. Toto and Joel are the two characters of this tale, who are forced to leave their place of origin and live in Europe.

The actions of Toto and Joel in the narrative propose two scenarios: Latin America and Spain. These are two different contexts that have a relationship between them because of the colonisation process, as Latin America was colonized by the Spanish Empire from the XV to the XIX centuries.. The boys' desires to go back to their hometown are a proof of how playful behavior can make them believe that they can go back to where they came from. Totó and Joel's actions somehow reject the colonisation of the past. Thus, playing is a way to rebel against a strange city and their parents, who force them to live there. Totó and Joel are not good students, but they become the best students as they want to go back to where they belong. The desire of returning to their place of origin is what some critics regard as a response to the colonisation in their countries in the past, the necessity of independence and the decision of being a free nation (Neo, 2006).

Play and adventure become a reflection upon the encounter of two worlds and its implications before and after the colonial period. Playing indicates the changes produced by the occupation of the new continent by the Spaniards. As Joel and Totó move to a strange city, they lose all that belongs to their previous lives. Colonisation implies the destruction, 
displacement and elaboration of new cultural values. Totó and Joel are creating, on their own, behaviors and procedures in an attempt to approach their roots Besides, it also explains the existence of the colonised people, which during their independence process re-invented their values in combination with the new ones, which had been imposed by external agents. Totó and Joel use playing to defy their parents' authority.

Asking for a boat in a building in Madrid, on the fifth floor, far from the sea seems senseless from a rational viewpoint, but this is how magic appears in everyday life with the family. In addition, it also expresses the convergence and distance between the boys and their parents. Children obey their parents and parents wish the best for their children. However, this convergence is broken by other variables: Cartagena is a tropical city and Madrid is a European city far away from the sea. The boys should be good students; this is what their parents demand. Nevertheless, this norm is broken by the boys' secret desires as they ask for a boat and then for a set of diving equipment to dive in their apartment and go back to the world of surrealism that they have been experiencing in the form of a game. The fact that the parents go to the cinema every Wednesday seems very logical, but it remains bizarre that the boys are entertained with the idea that they can sail and dive in the apartment. The parents are the passive spectators in the cinema, while the boys are the active actors of their own game.

The former encounters and their implications, as well as the rational and irrational elements make part of the reality, which is revealed from what is regarded as illogic. All this constitute magic, which in a way questions two distant and different worlds connected by the past: the language and the mixture of pre- and post-colonisation cultural elements. The language is the way to access this narrative and the boys' feelings in their new life: they long for a warmer environment, but they live in a new place now and they have to reinvent their world in order to survive. After complex socio-political 
processes, Latin America has been reinvented through revolutions, dictatorships, and other events which have created a cultural syncretism. Thus, Magical Realism is a reflection on those processes, which have not been necessarily in favour of the people involved.

Totó and Joel's behavior not only epitomise the system of pre and post-colonialists symbols, which is part of the interpretation, but it is also the author's judgement upon existence in general. The boys play a game which is limited and contains rules, so they consistently maintain and enjoy the game. Totó and Joel transgress their parents' authority when hiding what they used to do on Wednesdays. They also break their own game rules because they do not expect that their mates do not know how to dive or that the oxygen in their diving equipment is not enough for them to go on this adventure. They break the game rules by not having the necessary diving equipment for all the children in the apartment, and this brings tragic consequences upon themselves. Norms work as the defence against chaos and provide natural and human existence with order. Breaking these norms causes endless evils for the society and the environment (Vernant, 1990). The boys defy the established order; therefore they do not fulfil their own rules while their parents used to go to the cinema on Wednesdays. Ignoring adults' authority as well as creating their own rules every Wednesday has led to a tragedy; thirty seven classmates were dead as the result of this game when they went to celebrate the end of the school term in Toto and Joel's apartment. (García, 1992).

The tragedy that appears in Light is like Water, as well as in other Magical Realism works, is a reflection upon human beings and their existence in relation to conflicts recurrent in Latin American countries, as well as to the production and development that have been beneficial for some, but also deprives others of values which imply respecting humans and the environment. For example, this development benefited big 
corporations which exploited the natural resources of the countries where they operated, whereas it harmed the indigenous population who lived there by obliterating their environment.

\section{Si Tanggang: A Manifestation of Realism}

Si Tanggang constitutes part of the oral and written traditions in Malaysia. The story takes place in 1955, during the independence process, narrated within the context of the rough economic and political situation after the Japanese occupation, as well as the instability of England in its colonies (Watson and Andaya, 2001). Although this story does not reflect that historical moment, it shows the economic conditions that shape the various social classes and also addresses issues affecting the rural areas.

The story is about a family of low economic resources and shows the son's desire of getting a better socio-economic status and later going back to his village to help his parents. The sea becomes a way to achieve his goals; the sea, as a symbol of freedom, leads Si Tanggang to a new experience and takes him accidentally to his village again. Some of the events that occur in his returning trip show the struggles and cravings for independence of the country. As he goes and returns, it is possible to observe some elements that let us see interests, desires and the social composition in that time, which go along with Si Tanggang's original necessity of going back to his village.

Si Tanggang leads us to a historical moment in Malaysia around 1955. The period called "The Emergency", from 1948 to 1960, was the lapse of time when the opposition to the colonial regime was made stronger by guerrillas, which demanded preponderance in the life of the country. Unemployment increased, businesses failed, strikes grew, and the military clashes wore down the nation. Although the country gained independence in 1957, it would then face 
economic, political and racial problems, among others (Mahathir Mohamad, 2011).

Depression and the need of a new generation for a change in existence are expressed with a set of values and hierarchies that appear to produce the following human features. Firstly, the humility and authenticity reflected on the attitude of Si Tanggang's parents, who stay in a place that does not offer any material comfort but makes them feel rooted. Secondly, there is the persistence of Si Tanggang to find a job and to change his life. Furthermore, the seduction of power offered by wealth makes him forget about his motivations to find the sea (his initial goal) and freedom. The boat's owner has the ambition to increase his wealth, and this becomes evident in Si Tanggang's attitude and effort in helping him achieve it. Another feature is the submissiveness of the skipper's daughter, which is the continuation of what her father represents: power based on an economical position. God's magnificence listens to the boy's mother's wishes and restores the order destroyed by Si Tanggang. That is, the order that is symbolized by Si Tanggang, his wife and his ship turned into rock, as a manner of punishment. This event occurred after he looks forward to correcting the damage and disrespect caused by him, who returns and does not recognise his roots and the promises he has made to his parents.

Migration is another characteristic of the fiction of Realism. Si Tanggang does not leave his village for the city and he does not constitute a part of the new proletariat that is emerging from the industrial development. Instead, he goes to the sea which has been important for the Malaysian economy. Malaya was, from ancient times, a transit hub for ships carrying goods from all over the world, which has been an important factor for the economy. Si Tanggang's departure is a search for freedom.

$\mathrm{Si}$ Tanggang, the main character belongs to the bourgeoisie in Realism; he becomes the centre of the narration and the rest of the characters, who makes part of the society 
revolve around him (Barrueto and De la Cruz, 2008). In this story, he, does not belong to the bourgeoisie, but he longs to elevate himself to a higher social class and through experience, he has been able to do so. His parents live in a rural area and probably work in agriculture, like their neighbours. The owner of the ship represents the upper-class society and his daughter represents the continuity of her father's wealthy background in the aristocratic social class. Si Tanggang, as a worker in the ship, represents a low social class. However, as he worked, he became a salary earner, as his skipper surely payed him for his work. Therefore, Si Tanggang's social condition became different from his parents' and neighbours' social conditions.

Realistic narrative presents the author's ideological position through very precise descriptions, which are generally a denunciation. The author's position is evident in $\mathrm{Si}$ Tanggang, where he shows the rural area and its poor condition being in contrast to a wealthy social class represented by the owner of the ship. As this is a short story, it is not possible to see the whole view of the society; it only describes the composition of the rural areas whereas a space close to the urban context is not mentioned. Beliefs and superstitions make up part of many cultures and we can find them in Si Tanggang in relation to nature. . He has searched and found freedom in the sea, and gains a better economic situation. Finally, it is there where his life ends, when he breaks the balance of respect that should exist towards adults, and especially, his parents. He initially departs from his village with the intention of coming back. When he returns by accident, he does not recognise his mother. In doing so, he also does not recognise the place where he came from. The sea frees him, sees him grow up, and gives him the wealth that he desires so much. The sea takes him to his village again, but at the same time, sees him disappear with his wife, the product of his ambition.

\section{A Comparison: Light is Like Water and Si Tanggang}


Western thought seems to imposed a discourse that judges and condemns others cultures that are different from it. These societies are forced to leave their own traditions and thoughts, and gradually take the one that has been imposed as superior (Mata, 2008). The children in both stories live this process. Toto and Joel should leave their environment and relocate in the first world. They have to live in the fifth floor of an apartment in Madrid. However, they want to go back to their original environment, but they are not able to; therefore they invent it through magical resources. They create the sea, but they hide it from their parents, who represent the authority that imposes as the most valid.

In the same way, Si Tanggang leaves his place of origin, which is a rural area, and gets into the sea, the ideal that imposes the dominant worldview. Obtaining money to reach a higher social position becomes his goal. When he leaves his rural environment, he does it in order to find better living conditions and then he returns. However, the cultural values that he finds far from his village absorb him. The promise to return is abandoned and later confirmed when he pretends not to recognize his own mother.

In Light is like Water, Cartagena is a seaside city; it is the starting point and the place where the boys want to return to. In Cartagena, the sea gives them freedom and a sense of belonging. It is a tropical place, where the children spent their childhood, a stage in their life characterized by games, freedom, and innocence. On the other hand, in Si Tanggang, the starting point is not the sea; it is the rural area that represents freedom as well. The beginning of the two stories is characterised by the presence of the boys searching for new contexts, both located at the sea.

Totó and Joel's freedom represents the desire of going back to their roots. In other words, this is the desire of recovering part of the nation's culture as well as a continent mistreated by colonisation for centuries. Magical Realism can 
be regarded as a reflection on a continent which is still emerging from years of domination. Realism in Si Tanggang is also related to years of colonisation that, by the time the tale is written, has the country entrapped in a difficult economic situation. Si Tanggang, Totó and Joel are in a search represented by the adventure partially accepted by their parents because the boys may offer something in return to them: $\mathrm{Si}$ Tanggang offers better conditions for his parents; Totó and Joel promise to be excellent at school. In both cases, the parents are part of the boys' fantasies and they get involved in a project in the search for freedom and authenticity.

The way the boys make their dreams come true is magical in Light is like Water. On the other hand, the geographical and economic context is the only way to achieve a better social and economic position for Si Tanggang. The three boys start a journey and each one pursue their purpose: Totó and Joel get to go back to the sea and sail every Wednesday while their parents go to the cinema. Si Tanggang does not sail a real sea for fun, but he has to work in a ship to achieve his goal: wealth. The geographical contexts in the two stories are apparently different, but the magic of Light is like Water creates an ocean to be sailed as in happens in $\mathrm{Si}$ Tanggang. The boys' fantasy leads them to live new experiences.

Totó and Joel live their nocturnal adventures during the school year. It is a game played behind their parents' back; when their parents come home, the boys would pretend to sleep peacefully. The boys know that they are breaking the rules. Not only do they sail and dive, but they also watch TV programs for adults only. Their parents reward their good behavior at school and let them invite thirty-seven classmates to celebrate the end of the school term. This activity ends up in a tragedy; all the boys participate in sailing and diving in the apartment and they do not foresee that the oxygen tanks do not have enough air for them. The game ends up in tragedy, but the tragedy in García Márquez's works does not surprise us 
because it is about magical and real situations that colour the everyday life of Latin America. Reality in this continent exceeds fantasy. Tragedy is an essential part of these nations; it is present in everyday life and is caused by the lack of sound policies in relation to human aspects such as education, health, basic services, respect for nature and aboriginal cultures, rather than the particular interests of the elites who have everything. Death is a recurrent element in tales or novels of Magical Realism.

Si Tanggang also creates a sort of imbalance when disrespecting his parents, and his punishment, as in the case of Totó and Joel, is the way to re-establish the order that they have broken. In Si Tanggang, his mother's words are the preamble for his son's punishment and rectification for not recognizing his parents, with an implication to the fact that he no longer recognises his roots.

Tragedy is present in the two stories. In one story, there are magical events that end up wrong; in the other, there is a disrespectul behavior caused by the power and social status that money can grant. In the case of Si Tanggang, God appears to be a kind of mediator between the mother and her son. The words of the mother are interpreted by God and materialises them. This procedure could be regarded as magic and religious (Skeat, 1965). These two characteristics are the embodiment of the folklore and the many beliefs that have seemingly been instilled in the Malay culture.

\section{Conclusion}

In Light is like Water, when the boys want to go back to Cartagena they reject their stay in Madrid. The narrative questions the sense of belonging between these worlds: Latin America and Spain. Game, innocence and transgression of the norms are ways used to search for ideal worlds that are close to an expression of belonging. In Si Tanggang, leaving the place of origin is explained by the necessity of getting a better condition of life.. The sea is used in this search; the oceans 
have been a symbol for exploration or soul-searching that implies taking risks. Nevertheless, this is the way humans find their respective new worlds, and the sea has often taken people to their places of origin with different purposes. Now that the sense of origin is broken and weakened, like with Si Tanggang, who upon returning accidentally to his place of origin, this place does not provide him a sense of belonging. It is for this reason that once he arrives, he denies his roots after getting to know other values provided by wealth.

Literary creations may correspond to different historical periods, deal with different topics, belong to distant cultures, but all of them have in common the reflection on the human being, which represent an intercultural understanding between cultures; in this case through literature.. . Here we have the vision of human beings who participate in processes of freedom e as their prominent objective. Totó and Joel want to be free and they achieve it secretly. Si Tanggang finds a way to achieve his goals and to be free in the sea.

After many years of domination as a product of colonisation, and once independence is obtained, the nations are still searching for freedom as the domination has not finished yet. Even though the invader has been expelled, other sources of power exist that do not allow countries to be completely free. Totó, Joel and Si Tanggang have that need for freedom; they try to find it, but those desires are frustrated by different circumstances and tragedies. The most important aspect of these two stories is how freedom comes about.

Nature has a relevant role in the two stories because it is the way to achieve the goals of freedom, and when nature is far, it is invented as in Light is like Water. From Magical Realism, nature is fundamental because it recreates the tropic and the meaning of freedom, as well as the complexity of Latin America in particular. For Realism, nature is described as is and does not contain imaginary elements. Nature is in this case a good example of how two different literary styles deal with the same topic using different approaches. 
The three boys have found it impossible to go back to their place of origin. Toto and Joel find themselves in a 5-story apartment in Madrid far from the tropic and the sea. $\mathrm{Si}$ Tanggang finds the desire of social ascendance, and the power obtained from working and earning money have been circumstances that made it impossible for him to return. The origin is blurred because of the new worlds that the boys have found which does not lead them back to the initial condition when they first start the journey. Each of them has returned on their own, but they don't belong to those cultures and environments anymore. Tragedy is somehow a response to the return that does not have roots and have lost the essence because of external elements that are incorporated into their beliefs and lack a strong sense of belonging.

\section{Endnotes}

i. A family moves from the coastal Colombian city of Cartagena de Indias to the fifth floor of an apartment in Madrid, Spain. The two young boys, Toto and Joel, ask for a boat in return for their good grades. When their parents finally buy them the rowboat, they break the light bulbs in their home and the light comes flowing out like water. They use the light to navigate around their home every Wednesday while their parents are out at the cinema, and invite their friends to go sailing with them as well. The boys and their friends end up drowning in the light.

ii. A son leaves his poor parents to make a fortune and promises to return for them. He rises up the ranks and even marries the daughter of his boss, but his promise is soon forgotten. When he comes back to his homeland, he refuses to acknowledge them and his callous ways leads to tragedy.

\section{References}


KATHA - The Official Journal of the Centre for Civilisational Dialogue

Badrie, M. A. (2013). Red onion, white onion and other Malay legends and folklores. CreateSpace Independent Publishing Platform.

Barros, R., Gonzalez, A., Freire, M. (2006). Curso de literatura [Literature Course]. Madrid: Edelsa.

Barrueto, A and De la Cruz, J. (2008). El Realismo Literario. Unpublished thesis disertation. Universidad Nacional Mayor de San Marcos, Lima, Peru.

Canfield, M. (1996). Parodia, paradoja, cliché y fabulación en la obra de García Márquez [Parody, Paradox, cliché and romancing in the works of García Márquez]. Scrittori "contro": modelli in discussione nelle lettetatura iberiche. Vol 1, 359-384.

Carpentier, A. (2004). El reino de este mundo. Madrid: Alianza Editorial.

Colón, C. (2011). Diario de a bordo. L. Arranz (Ed.). Madrid: Edaf.

Dallmayr, F. (2002). Dialogue among Civilizations: Some Exemplary Voices. New York: Palgrave Macmillan.

Fernandez, D. (2008). Literatura Universal. Barcelona: Almadraba.

García, G. (1992). Doce cuentos peregrinos [Strange Pilgrims]. Buenos Aires: Editorial Sudamericana.

Gómez, C. (2011). De la India a las Indias y viceversa: relaciones literarias entre Hispanoamérica y Asia (siglo XX) [From India to America and viceversa: literary relations between Hispanic America and Asia]. Iberoamericana, XI, 42, 43-63. 
Mahathir bin Mohamad. (2011). A doctor in the house: the memoirs of Tun Dr. Mahathir Mohamad. Kuala Lumpur: MPH Group Printing.

Mata, M. G. (2008). Diálogos de civilizaciones: religiones semitas y espiritualidad. Dikaiosyne, 21, 45-57.

Neo, D. (2006). S. Hart and W. Ouyang (eds.). A companion to Magical Realism. Woodbridge: Routledge. Journal of Iberian and Latin American Research, 12:1, 105-107.

Omics International (n.d.) Retrieved on January 4, 2016 from: http://research.omicsgroup.org/index.php/Malaysian_literature.

Pérez, V. (2002). Notas sobre el Realismo Mágico [Notes about Magical Realism]. Minotauro Digital. Retrieved on June 30 , 2011 from www.minotaurodigital.net/textos.asp? art=51\&seccion=Literatu ra\&subseccion=articulos.

Roh, F. (1927) Realismo Mágico: Problemas de la pintura europea más reciente [Magical realism: Problems about current European painting]. Revista de Occidente 16-47, 274-301.

Skeat, W. (1965). Malay Magic: An Introduction to the Folklore and Popular Religion of the Malay Peninsular. London: Frank Cass \& Co. LTD.

Uslar, A. (1984). Letras y hombres de venezuela [Literature and men from Venezuela]. México: Fondo de cultura económica.

Uslar, A. (1986). Godos, Insurgentes y Visionarios [Goths, Insurgents and Visionaries]. Barcelona: Seix Barral.

Vernant, J. (1990). Myth and Society in Ancient Greece. New York: Zone Books. 
KATHA - The Official Journal of the Centre for Civilisational Dialogue

Wan, A. (2013). Proceedings from the Asian Conference on Film and Documentary 2013: Malaysian eStories: the Passing of oral Traditions. Osaka: The International Academic Forum.

Watson, B. and Andaya, L. (2001) A History of Malaysia. London: Palgrave Macmillan.

Yahya, Z. (2000). Si Tanggang's homecoming: Negotiating tradition and modernity. Indonesia and the Malay world. 28:80, 22-31 DOI: 10.1080/13639810050006512. 